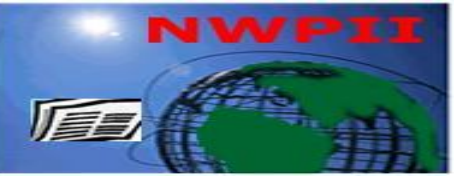

American Journal of Biomedical Sciences

ISSN: 1937-9080

nwpii.com/ajbms

\title{
Hemodynamic Forces-Induced Biochemical Changes in Aortic wall: Effect on Redox State of the Tissue
}

\author{
Husain Syed Yawer, Alok R. Ray, Shakir Ali*
}

Center for Biomedical Engineering, Indian Institute of Technology, New Delhi-110016.

* Department of Biochemistry, Hamdard University, New Delhi-1100 62.

Corresponding Author:

Husain Syed Yawer

Pulmonary and Critical Care

Dept. of Medicine, University of Chicago

5841 S. Maryland Avenue MC 6027,

Chicago, Illinois 60637

E.mail: hsyawer@gmail.com

Received: 9 November 2009; $\mid$ Revised: 2 March 2010; $\mid$ Accepted: 6 May 2010

\begin{abstract}
Shear stress and hydrostatic pressure-induced stretch are known to enhance the production of free radicals, causing oxidative stress in the vascular wall and have been implicated in endothelial inflammation and vascular lesions. Production of antioxidant enzymes such as superoxide dismutase, glutathione peroxidase, and catalase probably constitute a key factor in maintaining the redox state of arterial wall in response to hemodynamic forces. In the present study, redox state of arterial wall at constant pulsatile/laminar shear and varying hydrostatic pressure (70 and $150 \mathrm{~cm}$ water) was evaluated. The aim was to study the pressure, in combination with different flow patterns (laminar/pulsatile shear stress), induced oxidative stress which presumably cause arterial wall inflammation leading to vascular legions. The level of reduced glutathione (GSH), lipid peroxidation (LPO) and enzymes known to contribute to the redox status of the cell/tissue, have been measured. Present study quantitatively evaluates the hemodynamic forces induced vascular oxidative stress. We individually assessed the activity of Superoxide Dismutase (SOD), catalase, glutathione peroxidase (GPx), xanthine oxidase (XO), and glutathione-s-transferase (GST) under hemodynamic stress. Secondary antioxidant enzymes like glucose-6-phosphate dehydrogenase (G6PD) and glutathione reductase (GR) were also measured. The increased oxidative stress under pulsatile shear stress and high hydrostatic pressure potentially suggests that vascular inflammation is the key to understand initiation of vascular lesions. Higher concentrations of SOD in arterial wall ought to be considered since this explains arterial wall antioxidant defense in vascular pathologies, which potentially involve oxidative stress. In conclusion, pulsatile shear stress in combination with hydrostatic pressure is a weak inducer of antioxidant defense in blood vessels, hence, considered to be atherogenic. The finding is relevant to both the normal and pathophysiologically relevant hemodynamically stress rabbit thoracic aorta.
\end{abstract}

Keywords: hemodynamic forces; shear stress; pressure; pulsatile; laminar; endothelium; oxidative stress; arterial wall. 


\section{Introduction}

Hemodynamic forces-induced injury to the vessel wall could increase oxidative stress, which is encountered in many pathological situations affecting the vasculature. It has been well recognized that hemodynamic forces, which are constantly acting on the vessel wall, involved in vascular pathological process like atherogenesis. These forces (shear stress, hydrostatic pressure, and pulsatile stretch) alter function and structure of the blood vessel wall at cellular and molecular level. However, hemodynamic forces-induced intracellular ROS levels, or the role of ROS in hemodynamic forces-induced gene expression is yet to be elucidated further. Most of the cells that encompass the vascular system generate reactive oxygen species under normal and stressed conditions [1]. There is a conventional thought, which regard these highly reactive molecules as harmful to the vascular system, leading to some pathological processes such as hypertension and atherosclerosis [2, 3]. Rhythmic distension of the vessel wall, which is a component of pulsatile flow that imposes cyclic stretch on vessel wall, could play an important role in modulation of gene expression [4]. However, neither the intracellular levels ROS nor its role in hemodynamic forcesinduced gene expression has been fully understood.

Laminar shear stress increases superoxide dismutase activity in human aortic endothelial cells, thereby protecting vascular cells against oxidative stress. Pulsatile shear stress, on the other hand, is considered to be a critical determinant of flow-induced superoxide anion production [5]. The ability of laminar shear stress to induce GPx-1 expression in endothelial cells may be an important mechanism [6]. Glutathione may react directly with ROS as well as serve as an electron donor for glutathione peroxidase (GPx), which reduces hydrogen and lipid peroxides $[7,8]$.

Oxidant/antioxidant balance in arterial wall has a very important role in protecting the vessel and in permitting normal physiological and biochemical activities in the vessel $[9,10]$. In general, the amount of antioxidants is adequate to protect the arterial wall from any oxidant production that might occur under normal circumstances. In fact, the arterial wall contains very large amount of superoxide dismutase [11]. However, the antioxidant reserves can be inadequate under certain physiological stress conditions such as high blood pressure [12]. The behavior of ROS-producing systems (including a variety of NADPH and NADH oxidases, NO synthase, and xanthine oxidase) in vascular endothelium and smooth muscle cells are regulated by receptor-mediated action, metabolic processes, oxygen tension, and of course hemodynamic forces linked with blood pressure and flow $[13,14]$.

Vascular inflammation occurs in response to injury induced by various stimuli. Russell Ross in the late 1970s suggested in his "response to injury" hypothesis that atherosclerosis, at least, resulted from an initial injury to endothelial cells, leading to impaired endothelial function and subsequent macrophage infiltration and smooth muscle dysfunction. Thus, in contrast to the suggestion that what role could hemodynamics forces play in atherogenesis when inflammation and oxidant stress coincide. As a result of increase in reactive species (ROS), a number of pathophysiological responses are activated. These responses include attenuation of vasodilator mechanisms mediated through the stimulation of soluble guanylate cyclase and the promotion of adhesion protein expression or vascular proliferative processes. Prooxidant species become activators of apoptotic or necrotic cellular injury in case of increased cellular antioxidant systems [15].

The arterial wall is optimally active to neutralize normal levels of production of oxygen free radicals. Both endothelial cells and vascular smooth muscle cells are capable of producing reactive oxygen species from a range of enzymatic sources $[16,11]$. In some vasculopathies, such as atherosclerosis and hypertension, the production of these reactive oxygen species may increase to a large extent [17, 18]. The increase in the production of superoxide anion can lead to a decrease in ambient levels of nitric oxide through a simple radical/radical reaction that occurs much faster than the reaction of superoxide anion with superoxide dismutase $[19,20]$. The vessel wall is also able to generate increased levels of 
antioxidants when it is stressed by an oxidant injury [11].

Contrasting responses have been observed when vascular endothelium was exposed to pulsatile shear stress when compared with endothelium exposed to laminar shear stress. Earlier the vascular endothelium was not considered a major contributor of oxidative stress in normal aortas [21]. In contrast, the production of superoxide anion has been observed in medial and adventitial layer of the arterial wall explaining that radicals can be formed intracellularly, in the interstitial space and in the vascular space [11]. In the present study, the whole arterial preparation was considered.

So far, no studies have been devoted to test specific hemodynamic forces-mediated oxidative stress and antioxidant defenses in a whole artery preparation. In particular, the contribution of flow pulsatility, an important mechanical property of arterial circulation, has not been fully considered. In this study, potential role of pressure in combination with pulsatile or laminar shear stress has been investigated. Pulsatile flow at higher pressure has been implicated in weak vascular wall oxidative defense. A perfusion system was designed to impose a synergistic effect of pulsatile/laminar shear stress and pressure on rabbit thoracic aorta preparation to create a close simulation of the actual conditions occurring in vivo (Fig. 1).

At constant pulsatile/laminar shear and varying hydrostatic pressure, the level of reduced glutathione (GSH), lipid peroxidation (LPO) and enzymes known to contribute to the redox status of the cell/tissue have been measured. Enzymes measured in this study include superoxide dismutase (SOD), catalase, glutathione peroxidase (GPx) and xanthine oxidase (XO) and glutathiones-transferase (GST). Secondary antioxidant enzymes like glucose-6-phosphate dehydrogenase (G6PD) and glutathione reductase (GR) were also measured.

\section{Materials and methods}

\subsection{Solutions and chemicals}

The composition of Krebs solution, represented as mMol/L, was $118 \mathrm{NaCl}$; $4.7 \mathrm{KCl}$;
$25 \mathrm{NaHCO}_{3} ; 1.2 \quad \mathrm{KH}_{2} \mathrm{PO}_{4} ; 1.2 \quad \mathrm{MgSO}_{4} ; 2.5$ $\mathrm{CaCl}_{2}$; and 11 glucose. The perfusate contained bovine serum albumin (BSA) (Cohn Fraction V, Sigma, St Louis, USA) at a concentration of 10 $\mathrm{mg} / \mathrm{ml}$ in Krebs solution. Perfusates were warmed to $37{ }^{\circ} \mathrm{C}$ and $\mathrm{pH}$ adjusted to 7.4 , finally it was oxygenated with $95 \% \mathrm{O}_{2}+5 \% \mathrm{CO}_{2}$, prior to perfusion in the vessel. Reduced glutathione, oxidized glutathione, glutathione reductase, reduced nicotinamide adenine dinucleotide phosphate (NADPH), 1-chloro-2,4-dinitrobenzene (CDNB), 1,2-dithio-bis-nitrobenzoic acid (DTNB), thiobarbituric acid (TBA), xanthine, amionoguanidine (hemisulphate), glucose-6phosphate, nicotinamide adenine dinucleotide phosphate (NADP), 2,3-diaminonapthalene (DAN), sulphanilamide (Sigma Chemicals Co, $\mathrm{St}$ Louis, M.O, USA), nitrobluetetrazolium (NBT), Tris, EDTA, (SRL, India), Pyrogallol, $\mathrm{HCl}$ (Merck) and other chemicals of high purity/HPLC grade were used. All other chemicals used in the study were purchased from standard commercial sources in India.

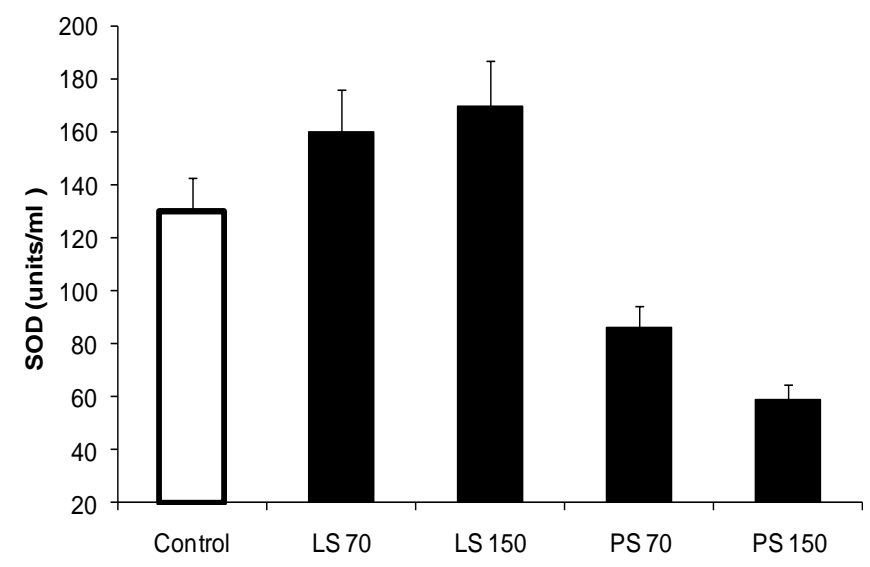

Fig. 1: Superoxide dismutase activity in normal and different hemodynamic conditions (LS 70, LS 150: Laminar shear stress (LS) at 70 and $150 \mathrm{~cm}$ water; PS 70, 150: Pulsatile shear stress (PS) at 70 and $150 \mathrm{~cm}$ water $)$. $(\mathrm{P}<0.05, \mathrm{P}<0.01$, and $\mathrm{P}<0.001)$

\subsection{Animal Model}

Thoracic aortas of male white rabbit were used for the study. All experiments were performed in accordance with the guidelines of the local animal ethics committee of the institute. 


\subsection{Perfusion system}

A perfusion system was designed with some modifications in a previously used perfusion systems by Baldwin et al [22]. It was designed as a close continuous flow loop. In this perfusion system, pressure was superimposed with flow through a pressure head with adjustable height, connected upstream to the vessel. The perfusate circulated between downstream and upstream reservoir, through a roller pump (Minipuls, Gilman, USA). All the tubings used in the system were of uniform diameter to maintain proper flow conditions.

For the experiments with pulsatile flow (shear stress) and pressure, a solenoid valve (Nachiketa Fluidomics, India), operated through a switching circuit of 1.6-3.0 Hz was introduced between upstream reservoir and outer vessel bath. A catheter tip pressure transducer (Excel Technologies, India) was attached through the lumen at the downstream end of the aorta. It was positioned as close as possible to the vessel to minimize the pressure drop down the length.

\subsection{Artery preparation}

Rabbits were anaesthetized by intravenous injection of $30 \mathrm{mg} / \mathrm{kg}$ body weight sodium pentobarbital via the marginal ear vein. The body weight and blood pressure were assessed and recorded regularly using sphygmomanometer, until the time of sacrifice. The trachea was intubated so that the animal could be ventilated mechanically. The sternum was split longitudinally and the aorta was exposed between the heart and the diaphragm. After dissecting away the surrounding fat, intercostal arteries were ligated (using silk thread), close to the aortic wall along a $4 \mathrm{~cm}$ length of the vessel. During the whole operation, the surface of the vessel was gradually warmed to a temperature of $37^{\circ} \mathrm{C}$ by superfusing with warm saline. Following this, a length of the aorta from the base of the aortic arch to the diaphragm, was taken out and cannulated without allowing the vessel to collapse.

Cannula whose width was adjusted to fit the internal diameter of the vessel were inserted and tied in place at both ends. Cannulation procedure described by Baldwin et al. [22] was followed.
The proximal cannula, just distal to the aortic arch, was connected to a reservoir containing 40 $\mathrm{mg} / \mathrm{ml}$ BSA-Krebs solution, which was kept at a height of $80 \mathrm{~cm}$ above the reservoir. The vessel was flushed with BSA-Kreb's solution to wash away the blood. The two cannulas were supported by a bridge, which allowed the artery to be maintained at in vivo length (as stretched naturally in the body). Checks were made for leaks and endothelial integrity with $0.02 \%$ Evans blue dye mixed in the BSA-Krebs solution. The vessel was then excised and transferred into a trough containing warm, oxygenated Krebs solution. All perfusion tubing as well as the vessel bath, housed in a water bath, was heated to $37 \pm 1.0{ }^{0} \mathrm{C}$ for accurate temperature control. By using sliding microscope the external diameter of normally pressurized aorta was measured $(3.07 \pm 0.09 \mathrm{~mm})$ in absence of longitudinal stretch and transmural pressure.

\subsection{Experimental design}

Shear stress was computed from flow rate and diameter measurements. The extent of flow pulsatility was calculated $(\dot{\alpha}=4.94)$ using a Womersley approximation [23]. Shear stress $(\tau)$ was calculated according to Poiseuille's law:

$$
\tau=\frac{4 \mu \mathrm{Q}}{\pi \mathrm{r}^{3}}
$$

Where $\mu$ is the perfusate viscosity in poise, $\mathrm{Q}$ is the flow rate $(\mathrm{ml} / \mathrm{sec}), r$, is the internal vessel radius. The value for wall shear stress was kept $\left(\right.$ Mean \pm SD) $1.0 \pm 0.05 \mathrm{dyne} / \mathrm{cm}^{2}$ at 70 or 150 $\mathrm{cm}$ water pressure. This relation explains the fact that relatively small decreases in vessel diameter at constant flow can markedly increase shear stress at the endothelial surface. The perfusate was allowed to circulate for the desired length of time. The design of the cannula ensured a fully developed laminar flow in the artery.

All the vessels were put under different hemodynamic conditions (laminar /pulsatile shear stress and varying hydrostatic pressure). Each aorta was exposed to either laminar shear stress and varying hydrostatic pressure $(70$ or $150 \mathrm{~cm}$ water) or pulsatile shear stress and varying (c) 2010 by NWPII. All rights reserved. 
hydrostatic pressure for $90.0 \pm 5.0$ minutes. It is to be mentioned here that shear stress is calculated under the assumption that the flow profile is parabolic (steady laminar flow), a situation, which is never realized in vivo due to the pulsatile nature of blood flow and the fact, that blood vessels are collapsible. Branching and bifurcation along the vascular tree together with a gradual decrease in diameter also disfavor the orderliness of stable flow profile. This entails that shear stress values calculated according to Poiseuille's law are much lower than the actual values in situ.

\subsection{Biochemical estimations}

Biochemical analyses of the control as well as stressed rabbit thoracic aorta were performed according to methods described below.

\subsection{Processing of the tissue and preparation of lysate (homogenate)}

The routine method standardized in our laboratory was used for preparation of tissue and subsequent subcellular fractionation. Aortas were taken from both the normal (control) and stressed groups. The vessels were quickly removed after the experiment, rinsed and placed in ice-cold 0.1 M phosphate buffer with $1 \mathrm{mM}$ EDTA, $\mathrm{pH}$ 7.0. The fat, mesenteries and perivascular connective tissue were removed. The vessels were then blotted gently between the folds of a filter paper filter paper and weighed. Cut pieces were minced before homogenization. A $10 \%$ homogenate was prepared in nine volumes of phosphate buffer $(0.1$ $\mathrm{M}, \mathrm{pH} 7.4$ ) containing $1.15 \% \mathrm{KCl}$ giving 5-6 strokes using a polytron homogenizer. All subsequent operations were carried out at a temperature between $0-4^{\circ} \mathrm{C}$ for biochemical analyses.

\subsection{Sub-cellular Fractionation}

Before subcellular fractionation, the homogenate $(10 \%)$ was passed through the muslin cloth. It was centrifuged at $1500 \mathrm{x} g$ for 5 minutes in a cooling centrifuge to remove the nuclei and other fibrous material. Some aliquots of so obtained supernatant were kept for measuring acid soluble thiol compound (GSH). The supernatant was then decanted into a fresh centrifuge tube and subjected to centrifugation first at $800 \mathrm{x} \mathrm{g}$ for 10 min and then $10,500 \times \mathrm{g}$ for 20 minute to get post mitochondrial supernatant (PMS) which was used as source of analyses for the biochemical estimations. All enzymatic estimations were completed on same day, immediately after the experiment.

\subsection{Enzyme estimations}

\subsubsection{Xanthine Oxidase (XO)}

Xanthine oxidase (XO) catalyses the conversion of xanthine to uric acid, which has a characteristic absorption peak around $290 \mathrm{~nm}$. The following spectrophotometric method for XO estimation is based on the procedure of Stripe and Corte [24] as modified by Ali et al. [25]. Briefly, $0.2 \mathrm{ml}$ of post mitochondrial supernatant was diluted to $1 \mathrm{ml}$ with tris-buffer $(0.5 \mathrm{M}, \mathrm{pH} 8.1)$ and incubated for $5 \mathrm{~min}$ at $37^{\circ} \mathrm{C}$. Adding of $0.1 \mathrm{ml}$ of $1.0 \mathrm{mM}$ xanthine started the reaction. The reaction was kept at $37^{\circ} \mathrm{C}$ for $20 \mathrm{~min}$. The reaction was terminated by the addition of $0.5 \mathrm{ml}$ ice-cold perchloric acid (10\%, v/v in distilled water). After $10 \mathrm{~min}, 2.5 \mathrm{ml}$ of distilled water were added to the precipitated mixture, which was then centrifuged at $1,200 \mathrm{x} g$ for $10 \mathrm{~min}$. The clear supernatant was decanted and the absorbance was read at $290 \mathrm{~nm}$. The results are expressed as $\mu$ moles of uric acid formed per $\mathrm{mg}$ protein. The activity of xanthine oxidase was calculated by using a $2 \mathrm{mM}$ stock solution of uric acid to prepare standard curve.

\subsubsection{Lipid Peroxidation (LPO)}

Assay was performed following the method of Bernheim et al. [26]. To a reaction mixture in a total volume of $2.0 \mathrm{ml}$ containing $1.8 \mathrm{ml}$ phosphate buffer $(0.1 \mathrm{M}, \mathrm{pH} 7.4), 0.2 \mathrm{ml}$ of the liver homogenate $(10 \% \mathrm{w} / \mathrm{v})$ was added. The reaction mixture was incubated at $37^{\circ} \mathrm{C}$ in shaker water bath for 1 hour. The reaction was terminated by adding $1.0 \mathrm{ml}$ of $10 \%$ trichloroacetic acid followed by the addition of $1.0 \mathrm{ml}$ of $0.67 \%$ thiobarbituric acid. All the tubes were kept in boiling water bath for 20 minutes. The tubes were then cooled in ice and centrifuged at 2,500 $\mathrm{x}$ g for 10 minutes. The resulting supernatant containing thiobarbituric acid-reactive substances (TBARS) was measured by taking the absorbance at $432 \mathrm{~nm}$ against a reagent blank. The results were (c) 2010 by NWPII. All rights reserved. 
expressed as nmole of malondialdehyde (MDA) formed $/ \mathrm{mg}$ protein at $37^{\circ} \mathrm{C}$ using a molar extinction coefficient of $1.56 \times 10^{5} \mathrm{M}^{-1} \mathrm{~cm}^{-1}$.

\subsubsection{Reduced glutathione (GSH)}

The assay was done according to the method of Jollow et al. [27] in which $1.0 \mathrm{ml}$ of the homogenate was precipitated with $1.0 \mathrm{ml}$ of $4 \%$ sulphosalicylic acid. The samples were then kept for 1 hour at $4^{\circ} \mathrm{C}$ and centrifuged at $1,200 \times \mathrm{g}$ for $15 \mathrm{~min}$ at $4^{\circ} \mathrm{C}$. The assay mixture consisted of 0.1 $\mathrm{ml}$ of above supernatant, $2.7 \mathrm{ml}$ of phosphate buffer $(0.1 \mathrm{M}, \mathrm{pH} 7.4)$ and $0.2 \mathrm{ml}$ of freshly prepared 5,5'-dithiobis-2-nitrobenzene (DTNB) (40mg in $10 \mathrm{ml}$ of $0.1 \mathrm{M}$ phosphate buffer of $\mathrm{pH7.4)}$ in a total volume of $3.0 \mathrm{ml}$. The color developed due to the formation of a yellow colored complex, 5-thio-2-nitrobenzoate, was measured immediately at $412 \mathrm{~nm}$. The activity was calculated using GSH as standard and expressed as $\mu$ mole of GSH/gm tissue.

\subsubsection{Superoxide Dismutase (SOD)}

SOD activity was measured with slight modification in previously used by Marklund et al. [28]. Pyrogallol autoxidation by superoxide dismutase radical $\left(\mathrm{O}^{2-}\right)$ generated by univalent reduction of oxygen, is inhibited by superoxide dismutase (SOD). SOD converts superoxide radical to $\mathrm{H}_{2} \mathrm{O}_{2}$, Which does not interfere with the autoxidation process (Marklund and Marklund, 1974).

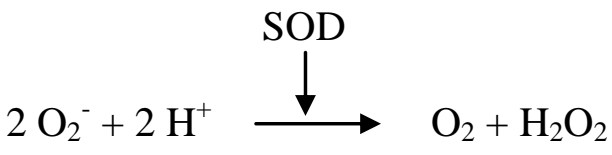

Tris buffer was prepared using Tris $(50 \mathrm{mM})$ and EDTA (1mM), dissolved in distilled water and then $\mathrm{pH}$ was adjusted to 8.5 by $\mathrm{HCl}$ and final volume made to $100 \mathrm{ml}$. Pyrogallol (20mM) solution was prepared in distilled water, freshly at the time of assay. Assay mixture contained $2.8 \mathrm{ml}$ of tris buffer, $0.1 \mathrm{ml}$ of pyrogallol and $0.1 \mathrm{ml}$ of sample (PMS). After an incubation period of 90 seconds, absorbance was recorded first in control and then in tests every 30 seconds time intervals for 3-4 minutes at $420 \mathrm{~nm}$. The rate of change of absorbance/min was noted at the given time interval and rate of change in the absorbance of the sample was noted to calculate the SOD activity. The increase in absorbance at $420 \mathrm{~nm}$ after addition of pyrogallol was inhibited by the presence of SOD in the sample. In this method one unit of SOD is described as the amount of enzyme required to cause $50 \%$ inhibition of pyrogallol autoxidation $/ \mathrm{ml}$ of sample and given by the formula i.e. units of SOD $/ \mathrm{ml}$ of sample $=(\mathrm{A}-\mathrm{B} / \mathrm{A}$ $\mathrm{x} 50) \times 100 \times$ dilution factor. Where $A$, is the difference of absorbance in $1 \mathrm{~min}$ in control, and $\mathrm{B}$, is the difference of absorbance in $1 \mathrm{~min}$ in test sample. Thus, the method was as sensitive as the method based on the reduction of cytochrome $\mathrm{c}$ by xanthine oxidase [50].

\subsubsection{Glutathione reductase (GR)}

Glutathione reductase activity was assayed by the method of Carlberg and Mannervick [29]. The assay mixture taken in a $3.0 \mathrm{ml}$ cuvette consists of $1.68 \mathrm{ml}$ of phosphate buffer $(0.1 \mathrm{M}, \mathrm{pH} 7.4), 0.1$ $\mathrm{ml}$ of $0.1 \mathrm{mM} \mathrm{NADPH}$ (freshly prepared by dissolving $0.833 \mathrm{mg}$ in $10 \mathrm{ml}$ of $0.1 \mathrm{M}$ phosphate buffer of $\mathrm{pH} 7.4), 0.1 \mathrm{ml}$ of $0.5 \mathrm{mM}$ EDTA (1.86 $\mathrm{mg}$ in $10 \mathrm{ml}$ of distilled water), $0.05 \mathrm{ml}$ of $1 \mathrm{mM}$ oxidized glutathione (freshly prepared by dissolving $6.126 \mathrm{mg}$ in $10 \mathrm{ml}$ of $0.1 \mathrm{M}$ phosphate buffer of $\mathrm{pH} 7.4)$ and $70 \mu \mathrm{l}$ of PMS (10\% w/v) in a final volume of $2.0 \mathrm{ml}$. The activity was measured in terms of decrease in absorbance at $340 \mathrm{~nm}$ at an interval of $30 \mathrm{sec}$ for $3.0 \mathrm{~min}$ at room temperature. The enzyme activity was calculated by measuring the disappearance of $\mathrm{NADPH}$ and calculated as nmole of NADPH oxidized/ $\mathrm{min} / \mathrm{mg}$ protein using molar extinction coefficient of $6.22 \times 10^{3} \mathrm{M}^{-1} \mathrm{~cm}^{-1}$.

\subsubsection{Glutathione peroxidase (GPx)}

Specific activity of the enzyme was measured according to the procedure described by Mohandas et al. [30]. The reaction mixture in a 3.0 $\mathrm{ml}$ cuvette, consists of $1.51 \mathrm{ml}$ of phosphate buffer (0.05M, pH 7.0), $0.1 \mathrm{ml}$ of $1 \mathrm{mM}$ EDTA (3.722 mg in $10 \mathrm{ml}$ of distilled water), $0.1 \mathrm{ml}$ of $1 \mathrm{mM} \mathrm{NaN}$ $(1.3 \mathrm{mg}$ in $20 \mathrm{ml}$ of distilled water), $0.1 \mathrm{ml}$ of $1 \mathrm{mM}$ reduced glutathione (freshly prepared by dissolving $3.07 \mathrm{mg}$ in $10 \mathrm{ml}$ of $0.05 \mathrm{M}$ phosphate buffer of $\mathrm{pH} 7.0$ ), $0.1 \mathrm{ml}$ of $0.2 \mathrm{mM}$ NADPH (freshly prepared by dissolving $1.67 \mathrm{mg}$ in $10 \mathrm{ml}$ of $0.05 \mathrm{M}$ phosphate buffer of $\mathrm{pH} 7.0$ ), $0.01 \mathrm{ml}$ of 
$0.25 \mathrm{mM} \mathrm{H}_{2} \mathrm{O}_{2}$ and $80 \mu \mathrm{l}$ of PMS (10\% w/v) in a final volume of $2.0 \mathrm{ml}$. The activity was measured in terms of decrease in absorbance at $340 \mathrm{~nm}$ suggestive of disappearance of NADPH at an interval of $30 \mathrm{sec}$ for $3.0 \mathrm{~min}$ at room temperature. The enzyme activity was calculated as nmole of $\mathrm{NADPH}$ oxidized/ $\mathrm{min} / \mathrm{mg}$ protein by using molar extinction coefficient of $6.22 \times 10^{3} \mathrm{M}^{-1} \mathrm{~cm}^{-1}$.

\subsubsection{Catalase (CAT)}

Catalase activity was assayed by the method of Claiborne et al. [31]. The assay mixture consisted of $1.99 \mathrm{ml}$ of phosphate buffer $(0.05 \mathrm{M}$, $\mathrm{pH} 7.0), 1.0 \mathrm{ml}$ of $\mathrm{H}_{2} \mathrm{O}_{2}(0.019 \mathrm{M})$ and $10 \mu \mathrm{PMS}$ $(10 \% \mathrm{w} / \mathrm{v})$ in a total volume of $3.0 \mathrm{ml}$. Decrease in the absorbance, which is indicative of disappearance of $\mathrm{H}_{2} \mathrm{O}_{2}$, was recorded at an interval of $30 \mathrm{sec}$ for $3.0 \mathrm{~min}$ at $230 \mathrm{~nm}$. The activity was expressed in nmole of $\mathrm{H}_{2} \mathrm{O}_{2}$ consumed/ min/ $\mathrm{mg}$ protein using the extinction coefficient of $0.081 \mathrm{x}$ $10^{3} \mathrm{M}^{-1} \mathrm{~cm}^{-1}$.

\subsubsection{Glutathione S-tranferase (GST)}

Glutathione S-transferase activity was measured by the method of Habig et al. [32]. The reaction mixture taken in a $3.0 \mathrm{ml}$ of cuvette consisted of $1.65 \mathrm{ml}$ of phosphate buffer $(0.1 \mathrm{M}$, $\mathrm{pH} 6.5), 0.2 \mathrm{ml}$ of $1 \mathrm{mM}$ reduced glutathione (freshly prepared by dissolving $3.07 \mathrm{mg}$ in $10 \mathrm{ml}$ of $0.1 \mathrm{M}$ of phosphate buffer of $\mathrm{pH} 6.5$ ), and 100 $\mu \mathrm{l}$ of PMS $(10 \% \mathrm{w} / \mathrm{v}) .50 \mu \mathrm{l}$ of $1 \mathrm{mM}$ freshly prepared 1-chloro-2, 4-dinitrobenzene $(2.03 \mathrm{mg}$ in $5-7 \mathrm{ml}$ of absolute alcohol; the solution was vortexed and the volume was made to $10 \mathrm{ml}$ with distilled water) was added making the volume of reaction mixture to $2.0 \mathrm{ml}$. The increase in absorbance corresponding to an increase in CDNB-conjugate formed was recorded at an interval of $30 \mathrm{sec}$ for $3.0 \mathrm{~min}$ at $340 \mathrm{~nm}$. The enzyme activity was calculated as nmole CDNB conjugate formed/ min/ $\mathrm{mg}$ protein using the extinction coefficient of $9.6 \times 10^{3} \mathrm{M}^{-1} \mathrm{~cm}^{-1}$.

\subsubsection{Glucose 6-phosphate dehydrogenase (G6PD)}

Glucose 6-phosphate dehydrogenase activity was assayed by the method of Zaheer et al. [33]. The reaction mixture in a total volume of $3.0 \mathrm{ml}$ in a cuvette consists of a $0.3 \mathrm{ml}$ of tris- $\mathrm{HCl}$ buffer Am. J. Biomed. Sci. 2010, 2(4), 295-312; doi: 10.5099/aj100400295
(0.05M, pH 7.6), $0.1 \mathrm{ml}$ of $0.1 \mathrm{mM}$ NADP (freshly prepared by dissolving $0.787 \mathrm{mg}$ in $10 \mathrm{ml}$ of $0.05 \mathrm{M}$ tris- $\mathrm{HCl}$ buffer of $\mathrm{pH} 7.6$ ), $0.1 \mathrm{ml}$ of $0.8 \mathrm{mM}$ glucose-6-phosphate (freshly prepared by dissolving $2.43 \mathrm{mg}$ in $10 \mathrm{ml}$ of $0.05 \mathrm{M}$ phosphate buffer of $\mathrm{pH} 7.6), 0.1 \mathrm{ml}$ of $8 \mathrm{mM} \mathrm{MgCl}_{2}$ (7.073 $\mathrm{mg}$ in $10 \mathrm{ml}$ of distilled water), $100 \mu \mathrm{l}$ of PMS $(10 \% \mathrm{w} / \mathrm{v})$ and $2.30 \mathrm{ml}$ of distilled water. The changes in the absorbance were recorded at an interval of $30 \mathrm{sec}$ for $3.0 \mathrm{~min}$ at $340 \mathrm{~nm}$ and the enzyme activity was calculated as nmole of NADP reduced/ $\mathrm{min} / \mathrm{mg}$ protein by using molar extinction coefficient of $6.22 \times 10^{3} \mathrm{M}^{-1} \mathrm{~cm}^{-1}$.

\subsection{Estimation of protein}

Protein from each tissue sample was determined using the method of Lowry et al. [34]. $0.1 \mathrm{ml}$ of the sample tissue $(10 \% \mathrm{w} / \mathrm{v})$ was diluted to $1.0 \mathrm{ml}$ with distilled water and then the protein was precipitated with equal volume of trichloroacetic acid $(10 \% \mathrm{w} / \mathrm{v}$ in distilled water) to get rid of other contaminants in the sample. Samples were kept overnight and centrifuged at $800 \mathrm{x} \mathrm{g}$ for 15 minutes. The supernatant was decanted and discarded. The pellet was dissolved in $5 \mathrm{ml}$ of $1 \mathrm{~N} \mathrm{NaOH}$ by vortexing. Finally $0.1 \mathrm{ml}$ of the diluted aliquot was taken and diluted further to $1.0 \mathrm{ml}$ with distilled water before adding $2.5 \mathrm{ml}$ of copper reagent, which was prepared by mixing sodium carbonate $(4 \% \mathrm{w} / \mathrm{v} 1 \mathrm{~N} \mathrm{NaOH})$ and sodium potassium tartarate $(2 \% \mathrm{w} / \mathrm{v}$ in distilled water) and copper sulphate $(2 \% \mathrm{w} / \mathrm{v}$ in distilled water) in the ratio of 48:1:1. The reaction mixture was kept for 10 min to allow complex formation and then 0.25 $\mathrm{ml}$ of Folin's reagent $(1 \mathrm{~N})$ was added. The absorbance of the blue color developed was recorded at $680 \mathrm{~nm}$. For standard curve, BSA (Bovine Serum Albumin) was used.

\section{Results}

\subsection{Effect of hemodynamic forces on wall oxidative stress}

Superoxide dismutase (SOD) activity: All the vessels were subjected to laminar/pulsatile flow $(1.6 \mathrm{~Hz})$ induced shear stress $(1.0 \pm 0.05$ $\left(\right.$ Mean \pm SD) dyne $\left./ \mathrm{cm}^{2}\right)$ at 70 and $150 \mathrm{~cm}$ water pressure for $5.0 \pm 0.5$ hours. The activity of superoxide dismutase was found to increase 
significantly (Fig 1) with laminar shear stress at both 70 and $150 \mathrm{~cm}$ hydrostatic pressures (160.0 \pm 14.0, $170.0 \pm 12.0$ units $/ \mathrm{ml}(\mathrm{P}<0.01)$, respectively, when compared with control (130.0 $\pm 15.0 \mathrm{unit} / \mathrm{ml})$. The increase was slightly higher at $150 \mathrm{~cm}$, suggesting an atheroprotective role of laminar shear stress. On the other hand, with pulsatile shear stress, a significant reduction in arterial wall SOD production at both the pressures 70 and $150 \mathrm{~cm}(80.0 \pm 6.5,59.0 \pm 5.7$ units $/ \mathrm{ml},(\mathrm{P}$ $<0.001)$, respectively, vs. control $130.0 \pm 15.0$ unit $/ \mathrm{ml}$ ) was observed. The low value of SOD at higher pressure $(150 \mathrm{~cm})$ predicts a determining role of pressure in combination with pulsatile shear stress in inducing vascular oxidative stress.

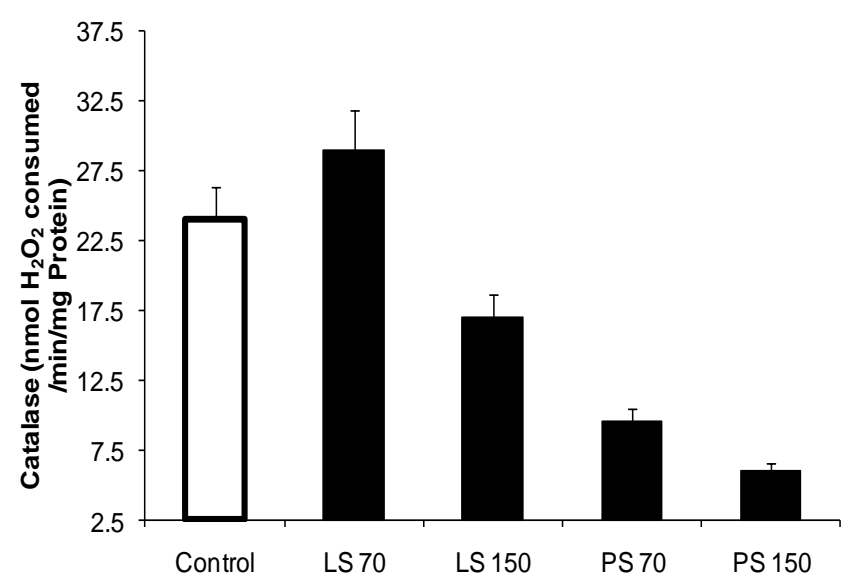

Fig. 2: Catalase activity in normal and different hemodynamic conditions (LS 70, LS 150: Laminar shear stress at 70 and $150 \mathrm{~cm}$ water; PS 70, 150: Pulsatile shear stress at 70 and $150 \mathrm{~cm}$ water). ( $\mathrm{P}<0.05$, $\mathrm{P}<0.01$, and $\mathrm{P}<0.001$ )

Catalase activity: The profile of catalase activity in different hemodynamic situations, explain the influence of pressure variation on catalase (Fig. 2). Laminar shear stress at lower pressure $(70 \mathrm{~cm})$ elevated the level of catalase $(29.0 \pm 3.3$ nmol vs. $24.0 \pm 4.3 \mathrm{nmol}, \mathrm{P}<0.01)$. While at higher pressure $(150 \mathrm{~cm})$, laminar shear stress was found to decrease catalase level significantly $(17.0 \pm 2.3 \mathrm{nmol}, \mathrm{P}<0.05)$. Further, with the pulsatile flow at both pressures (70 $\mathrm{cm} / 150 \mathrm{~cm}$ ), catalase was found to be significantly reduced. However the reduction was more significant at higher pressure $(150 \mathrm{~cm}, 6.0 \pm 1.8$ nmol, $\mathrm{P}<0.01 ; 70 \mathrm{~cm} ; 9.5+1.5 \mathrm{nmol}, \mathrm{P}<$ 0.001 ), suggesting a prominent role of pressure on catalase level.

Glutathione peroxidase (GPx): Exposure of the vessel to laminar/pulsatile shear stress and varying hydrostatic pressure had a profound impact on the enzymatic activity of glutathione peroxidase (Fig. 3). Laminar shear stress significantly elevated GPx level at both higher pressures $(70 \mathrm{~cm}, 8.8 \pm 1.9 \mathrm{nmol}$ vs. control, $5.9 \pm$ $2.3 \mathrm{nmol}, \mathrm{p}<0.01)$. While at higher pressure, laminar shear stress was found to cause a slight reduction in GPx activity $(150 \mathrm{~cm}, 7.8 \pm 1.3 \mathrm{nmol}$, $\mathrm{P}<0.01)$. Pulsatile shear stress, on the other hand, at both 70 and $150 \mathrm{~cm}$ pressures, significantly reduced GPx activity (Fig. 5). However, reduction was much lower at $70(2.2 \pm 0.57 \mathrm{nmol}, \mathrm{P}<0.05)$ than observed at $150 \mathrm{~cm}(4.1 \pm 0.5 \mathrm{nmol}$ vs. control $5.9 \pm 2.3$ nmol, $\mathrm{P}<0.01$ ), suggesting an opposing effect of hydrostatic pressure, in laminar and pulsatile flow, on GPx activity. This provides evidence to proatherogenic role of pulsatile shear stress.

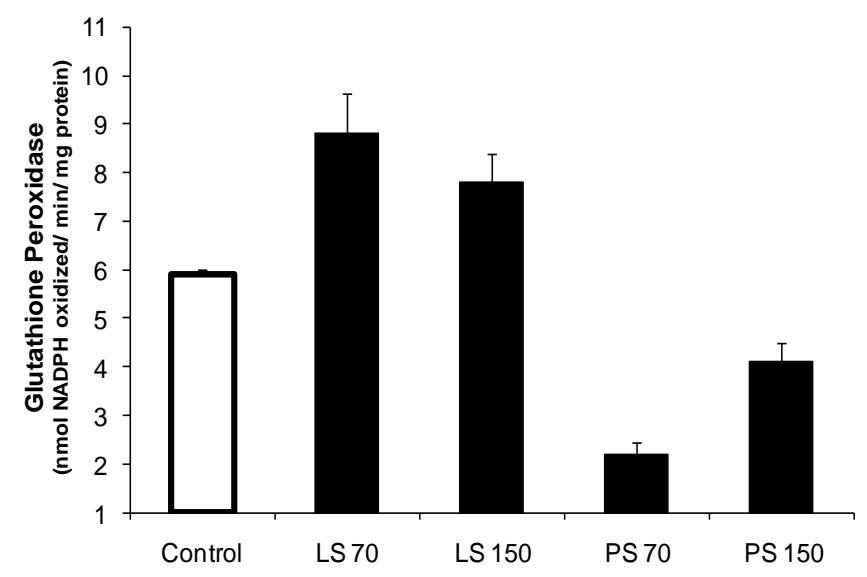

Fig. 3: Glutathione peroxidase activity in normal and different hemodynamic conditions (LS 70, LS 150: Laminar shear stress at 70 and $150 \mathrm{~cm}$ water; PS 70, 150: Pulsatile shear stress at 70 and $150 \mathrm{~cm}$ water). $(\mathrm{P}<0.05, \mathrm{P}<0.01$, and $\mathrm{P}<0.001)$.

\section{Glucose-6-phosphate}

dehydrogenase (G6PD): The activity of glucose-6-phosphate dehydrogenase enhanced in case of pulsatile shear stress at both pressures $(3.8 \pm 0.79$, and $4.7 \pm 0.6$ nmol at 70 and $150 \mathrm{~cm}$, respectively (Fig. 4). The control value was $2.9 \pm 0.6 \mathrm{nmol}$. In case of 
laminar shear stress, G6PD activity reduced. The reduction was, however, more prominent at $70 \mathrm{~cm}$ $(0.8 \pm 0.15 \mathrm{nmol}, \mathrm{P}<0.01)$ than observed at 150 $\mathrm{cm}(9.0 \pm 0.26 \mathrm{nmol}, \mathrm{P}<0.05)$, indicating the effect elevated pressure on G6PD activity.

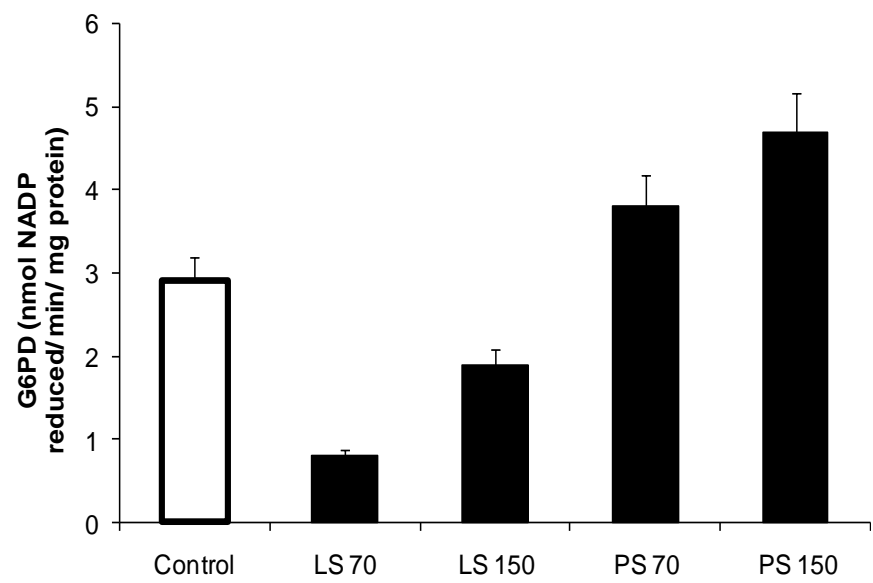

Fig. 4: Glucoase-6-phosphate dehydrogenase activity in normal and different hemodynamic conditions (LS 70, LS 150: Laminar shear stress at 70 and $150 \mathrm{~cm}$ water; PS 70, 150: Pulsatile shear stress at 70 and 150 $\mathrm{cm}$ water $)$. $(\mathrm{P}<0.05, \mathrm{P}<0.01$, and $\mathrm{P}<0.001)$

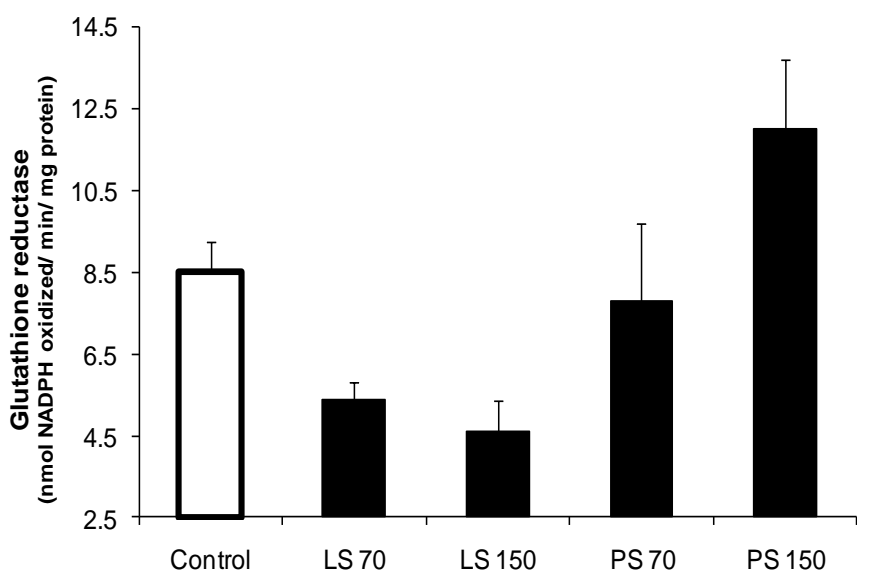

Fig. 5: Glutathione reductase activity in normal and different hemodynamic conditions (LS 70, LS 150: Laminar shear stress at 70 and $150 \mathrm{~cm}$ water; PS 70, 150: Pulsatile shear stress at 70 and $150 \mathrm{~cm}$ water). $(\mathrm{P}<0.05, \mathrm{P}<0.01$, and $\mathrm{P}<0.001)$

Glutathione reductase (GR): Pulsatile shear stress at $150 \mathrm{~cm}$ significantly elevated glutathione reductase activity $(12.0 \pm 4.1$ vs. $8.5 \pm 1.7 \mathrm{nmol}, \mathrm{P}$ $<0.05)$ (Fig 5). The reduction was slight at lower pressure, $70 \mathrm{~cm}(7.8 \pm 3.8 \mathrm{nmol})$, indicating proatherogenic role of pulsatile flow, as it can be clearly predicted at higher pressure. While with laminar shear stress pressure, the activity of GR was considerably downregulated at both 70 and $150 \mathrm{~cm}$ water pressure. However, the reduction was more prominent at $150 \mathrm{~cm}(4.6 \pm 1.7 \mathrm{nmol}, \mathrm{P}$ $<0.01)$ than observed at $70 \mathrm{~cm}(5.4 \pm 0.88 \mathrm{nmol}$, $\mathrm{P}<0.01)$.

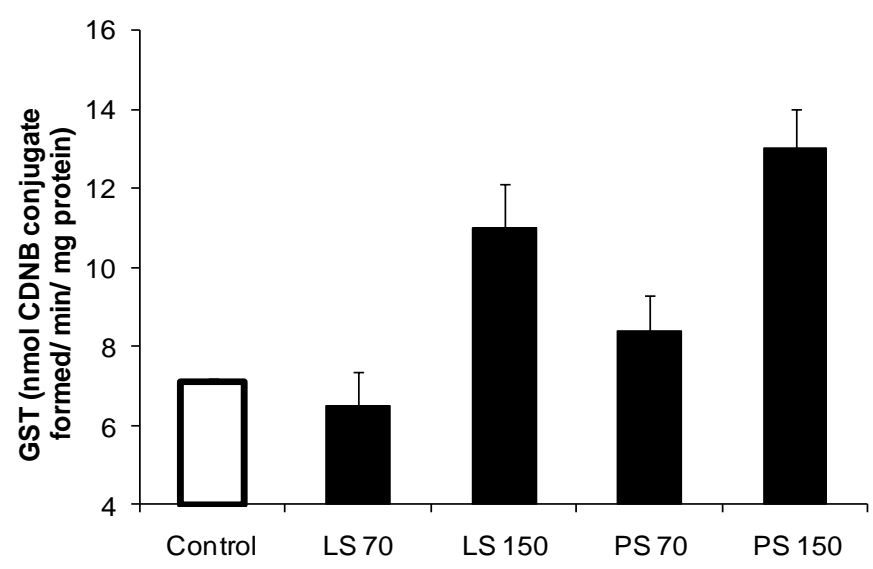

Fig. 6: Glutathione-S-transferase activity in normal and different hemodynamic conditions (LS 70, LS 150: Laminar shear stress at 70 and $150 \mathrm{~cm}$ water; PS 70, 150: Pulsatile shear stress at 70 and $150 \mathrm{~cm}$ water). $(\mathrm{P}<0.05, \mathrm{P}<0.01$, and $\mathrm{P}<0.001)$

\section{Glutathione-s-transferase}

(GST):

Glutathione-s-transferase activity is one of the key indicators of oxidative stress level in the cell. The glutathione-s-transferase is a ubiquitous enzyme that catalyzes the conjugation of reduced glutathione $(\mathrm{GSH})$ with reactive oxygen species. Pressure variations affect GST (Fig. 6). Pulsatile shear stress increases GST level at both 70 and $150 \mathrm{~cm}$ water $(8.4 \pm 0.89(\mathrm{P}<0.05), 13.0 \pm 2.3,(\mathrm{P}$ $<0.01)$, respectively, vs. control; $7.1 \pm 2.3)$. The activity was higher at $150 \mathrm{~cm}$. Laminar shear stress at $150 \mathrm{~cm}$ could elevate the GST level (11.0 $\pm 1.1(\mathrm{P}<0.01)$. At lower pressure $(70 \mathrm{~cm})$, no significant change was observed in GST activity level.

Reduced glutathione (GSH): The level of reduced glutathione was found to be decreased with pulsatile shear stress at 70 and $150 \mathrm{~cm}$ pressures. Pressure variation did not seem to influence GSH level (Fig. 7). On the other hand, laminar shear stress upregulated GSH level (6.1 \pm

(C) 2010 by NWPII. All rights reserved. 
$0.68(\mathrm{P}<0.05) ; 6.5 \pm 0.74(\mathrm{P}<0.01)$ vs. control; $4.9 \pm 0.5)$. At higher pressure $(150 \mathrm{~cm})$ with pulsatile shear stress and lower pressure with laminar flow at $70 \mathrm{~cm}$, the change was quite significant (laminar, $6.5 \pm 0.74(\mathrm{P}<0.01)$; pulsatile, $3.3 \pm 0.47,(\mathrm{P}<0.05)$ in comparison to control.

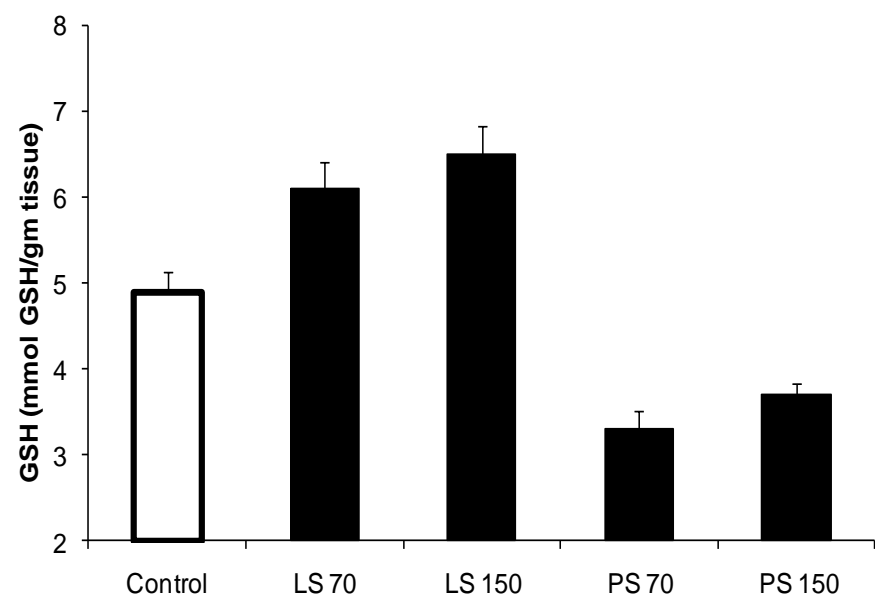

Fig. 7: Reduced glutathione (GSH) in normal and different hemodynamic conditions (LS 70, LS 150: Laminar shear stress at 70 and $150 \mathrm{~cm}$ water; PS 70, 150: Pulsatile shear stress at 70 and $150 \mathrm{~cm}$ water). $(\mathrm{P}<0.05, \mathrm{P}<0.01$, and $\mathrm{P}<0.001)$

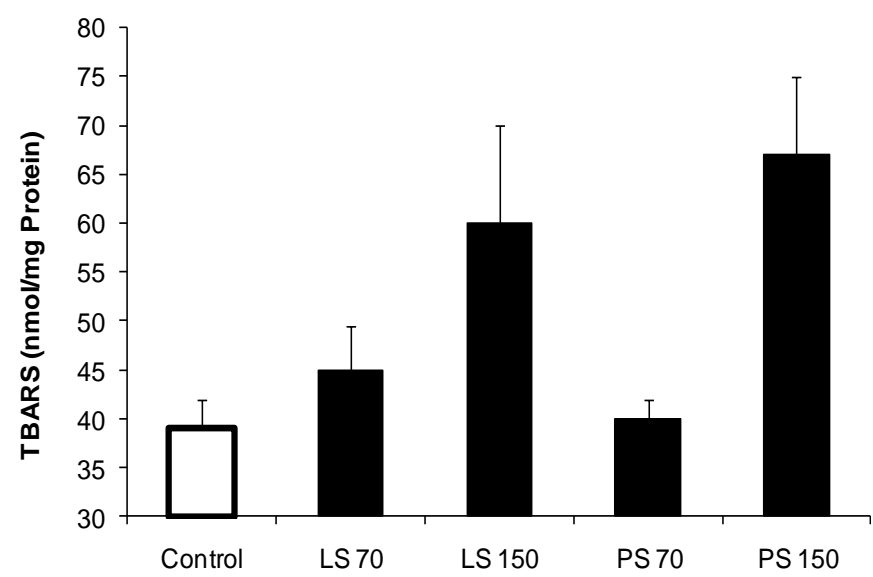

Fig. 8: Lipid peroxidation in TBARS activity in normal and different hemodynamic conditions (LS 70, LS 150: Laminar shear stress at 70 and $150 \mathrm{~cm}$ water; PS 70, 150: Pulsatile shear stress at 70 and $150 \mathrm{~cm}$ water). $(\mathrm{P}<0.05, \mathrm{P}<0.01$, and $\mathrm{P}<0.001)$

Lipid peroxidation (LPO): Hydrostatic pressure was found to play a determining role in modulating lipid peroxidation. If we consider the profile (Fig. 8) of LPO in vessels, exposed to laminar and pulsatile shear stress at $150 \mathrm{~cm}$, a considerable increase in lipid peroxidation level (laminar, $60.0 \pm 2.2, \mathrm{P}<0.01$, pulsatile; $67.0 \pm 17$, $\mathrm{P}<0.01$ vs control; $3.9 \pm 6.7 \mathrm{nmol} / \mathrm{mg}$ protein) is evident. While at lower pressure $(70 \mathrm{~cm})$, the change was not significant. A slight elevation in LPO with laminar shear stress was observed (45.0 $\pm 10.0, \mathrm{p}<0.05$ vs. control; not significant).

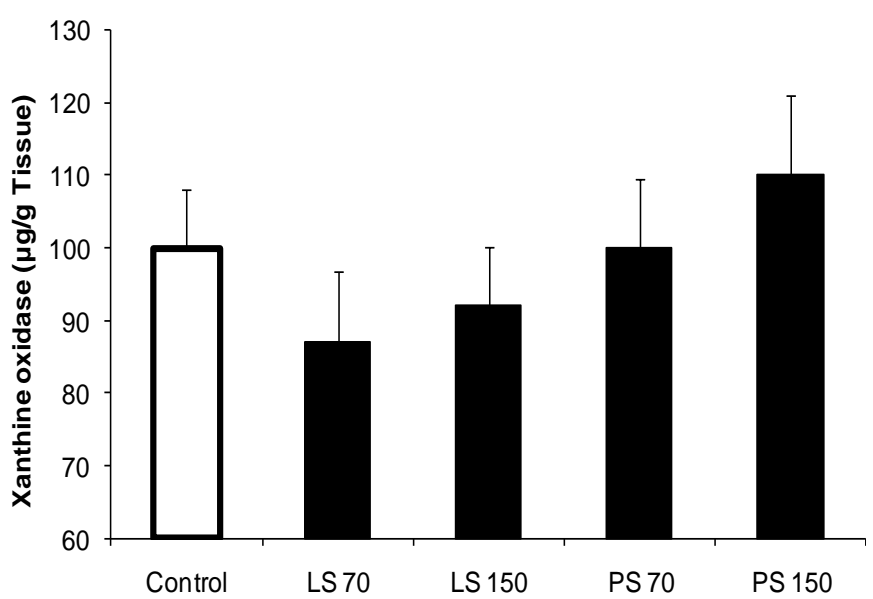

Fig. 9: Xanthine oxidase activity in normal and different hemodynamic conditions (LS 70, LS 150: Laminar shear stress at 70 and $150 \mathrm{~cm}$ water; PS 70, 150: Pulsatile shear stress at 70 and $150 \mathrm{~cm}$ water). $(\mathrm{P}<0.05)$

Xanthine oxidase (XO): Exposure of all the vessels to different hemodynamic condition did not seem to influence the xanthine oxidase activity significantly (Fig. 9). A slight reduction in XO activity with laminar shear stress at $150 \mathrm{~cm}[92.0$ $\pm 8.2, \mathrm{P}<0.05$ vs. control; $100.0 \pm 8.1(\mu \mathrm{g} / \mathrm{g}$ tissue), not significant] was observed. At higher pressure $(150 \mathrm{~cm})$ with pulsatile shear stress, XO was upregulated slightly $(110.0 \pm 11, \mathrm{P}<0.05$ vs. control, not significant). In case of laminar shear stress at $70 \mathrm{~cm}$, a slight reduction in $\mathrm{XO}$ activity was observed in comparison to control. While at lower pressure (70 $\mathrm{cm}$ water), the reduction was more marked.

\subsection{Statistical Analysis}

(C) 2010 by NWPII. All rights reserved. 
Results have been expressed as Mean \pm SD and analyzed (comparisons vs. controls) by using Student's- $t$-test. $\mathrm{P}<0.05,0.01$, and 0.001 was chosen as the level of significance.

\section{Discussion}

Oxidative stress can modulate a wide variety of biological processes by coupling signals at the cell surface into long-term changes in gene expression. Mechanical forces, for example, have been revealed to mediate the synthesis and secretion of endothelium-derived autacoids [35], which further alter protein synthesis and cell proliferation. It has earlier been studied by Hishikawa et al. that elevated levels of pulsatile flow modulates the formation of reactive oxygen species in human aortic endothelial cells and coronary artery smooth muscle cells. It has been shown that pulsatile stretch increases oxidative stress and, in turn, promotes DNA synthesis in cultured human coronary artery smooth muscle cells [36].

The influence of pulsatile shear and stretch on vascular smooth cell reactive oxygen species production has not been fully elucidated yet. In a study by Howard et al. [12], investigators did not explain an increase in cyclic pressure/strain induced superoxide production in vascular smooth muscles. One of the possible reasons given, was the exposure of cells to a sub-threshold level of pressure. It has been revealed [37] that since superoxide anion radical crosses the cell membrane poorly, the SOD isoenzymes wield their protective functions in different arterial wall compartments. $\mathrm{H}_{2} \mathrm{O}_{2}$, owing to its stability and neutrality, is more likely to enter adjacent cells. In addition, the potential redox reactions of superoxide and hydrogen peroxide are quite different. Superoxide is more capable of acting as a reducing agent, whereas hydrogen peroxide and its fenton product, hydroxyl radical, are more likely to act as oxidizing agents. It has also been suggested that oxidative stress induced protein expression is involved in response of smooth muscle cells to shear stress (16). An antioxidant, pyrrolidine dithiocarbamate and BXT-51072 (that mimic glutathione peroxidase activity) could suppress shear-induced nitric oxide synthase induction in smooth muscle cells. This suggests an increased intracellular nitric oxide activity when there is low oxidant level in the vascular cells.

Lack of pulsatility in unidirectional flow did not bring about increase in superoxide anion production after $5.0 \pm 0.5$ hours flow exposure. This observation stresses the importance of flow pulsatility when assessing the redox state of the vessel wall exposed to different hemodynamic conditions. Studies reported by De Keulenaer et al. [38], have explained NADH-oxidase activity induction only in vascular endothelial exposed to pulsatile shear stress, whereas only laminar shear stress was unable to preserve a constant enzyme activity. However, their data were obtained using a cultured endothelial cells preparation. Cyclic pressure/strain-mediated superoxide generation has been confirmed previously in human aortic endothelial cells and coronary artery smooth muscle cells [36] and it was attributed to an increase in NADPH oxidase activity. Increased level of glucose-6-phosphate dehydrogenase (G6PD) activity with pulsatile flow especially at higher-pressure support the recycling of GSH. Glucose-6-phosphate dehydrogenase, the first enzyme in the pentose phosphate pathway, is an important source of NADPH and therefore, play a part in the defense against oxidative stress [39]. G6PDH activity is increased when GSH stores are depleted and, in turn, promotes the formation of GSH from its oxidized form, GSSG, to restore the cellular redox state.

It is well established that G6PDH-derived $\mathrm{NADPH}$ is utilized as a cofactor and substrate for several cellular enzyme systems, including glutathione reductase, nitric oxide synthase, and NADPH oxidase [40]. The increase in G6PD activity was found to be associated with decrease in glutathione peroxidase (GPx) activity, suggesting that G6PD modulated basal antioxidant defense in blood vessels [41]. Effect of mechanical forces on G6PDH activity has not been previously investigated in an intact blood vessel. We hypothesized that the aortic wall modulates the adverse impact of hemodynamic forces by increasing the expression/activity of glucose-6-phosphate dehydrogenase (G6PDH) to maintain intracellular glutathione (GSH) levels. Pulsatile shear stress, especially at higherpressure, induced superoxide formation, which 
resulted in diminished GSH because of an increase in oxidized glutathione formation (Fig. 7 and Tab. $3,4)$. An increase in glutathione peroxidase and glutathione reductase activities was also observed. G6PDH activity enhanced concomitant with decreases in GSH levels and remained elevated until intracellular GSH levels were restored. These observations are in agreement with a study (42) in which vascular smooth muscle cells were subjected to pulsatile pressure (cyclic stretch), which promoted the formation of reactive oxygen species.

In the present study including normal and pathophysiologically relevant hemodynamically stressed rabbit thoracic aorta, pulsatile shear stress in combination with hydrostatic pressure has been reported as a weak inducer of antioxidant defense mechanism in blood vessels. De Keulenaer et al. [38] have examined the redox state of cultured human umbilical vein endothelial cells after either pulsatile/oscillatory or steady laminar fluid shear stress and explained that atherosclerotic lesions are found opposite vascular flow dividers (at branches) at sites of low shear stress and pulsatile flow. Present observations are consistent with their hypothesis that suggests that a continuous pulsatile shear causes a sustained activation of oxidative processes. Further, steady laminar shear stress initially activates these processes but appears to induce compensatory antioxidant defenses (Table 3).

Variation in hydrostatic pressure was found to elevate the oxidative stress level, especially at higher value $150 \mathrm{~cm}$ water, which represents the hypertensive situation. Consequently increased superoxide activity imposed an oxidative stress in the vessel as demonstrated by decreased GSH level and increase in GSSG formation (Fig. 7, Table $1 \&$ Table 2). The significance of increased superoxide dismutase correlating with protection from free radicals suggests that laminar shear stress is inducing an atheroprotective response. This change in vascular thiol redox status is accompanied by elevated activity of glutathione-stransferase (GST) and glutathione reductase (GR) (Fig. 6 and Fig. 7), indicating an increase in GSH recycling. GSH is an endogenous tripeptide known for its role in maintaining redox status of the arterial tissue [43]. Its recycling from GSSG requires NADPH, which in a cell largely synthesized by G6PD.

Laminar shear stress was found to elevate cellular GSH level at both high and low hydrostatic pressures. Further, the decreased activity GR and GST was recorded which was accompanied by decreased activity of G6PD, although higher pressure was to elevate GST activity (Fig. 6). On the other hand, if we look at the level of superoxide dismutase (SOD) activity, laminar shear stress appears to behave as an antiatherogenic mechanical force by stimulating some antioxidant defense in blood vessels (Table 3). Increased activity of superoxide dismutase at both high and low pressure was associated with increased GPx activity at higher and catalase activity at lower pressure. Increased level of catalase activity was associated with a decrease in GPx activity at $150 \mathrm{~cm}$ water pressure (Table $1 \&$ Table 2). These data show an opposing effect pressure on catalase activity in vessel wall.

The cumulative amount of thiobarbituric acid reactive substances (TBARS) is measured as an index of lipid peroxidation. Increased lipid peroxidation (LPO) explains the elevated level of oxidative stress and causes instability of cellular membrane. Pressure in combination with laminar/pulsatile shear stress was found to increase LPO in blood vessels. Low pressure with both laminar and pulsatile shear stress did not seem to elevate LPO in aorta, but at higher pressure LPO has significantly increased with pulsatile flow (Fig. 8 and Table 4) explaining proatherogenic role of pulsatile shear stress in hypertensive conditions in vivo. Howard et al. [12] have explained earlier that hypertension imposed an oxidant stress on the aorta, causing mechanical deformation of the aortic wall. They reported an increase in LPO in porcine aortic endothelial cells (PAEC) subjected to pulsatile flow or cyclic strain.

As far as the activity of xanthine oxidase is concerned, we could not find a determining role of hemodynamics in imposing a regulatory effect on $\mathrm{XO}$ activity. The level of xanthine oxidase activity has been measured to determine the amount of superoxide produced in vessel wall [44]. Shear stress and pressure did not have significant impact on production of vascular xanthine oxidase. XO 
was investigated as source of ROS in generating oxidative stress in arterial wall. Although, the major source of ROS in vascular system is NADPH oxidase $[45,46]$ in endothelium, xanthine oxidase appeared to be a major superoxide generating system in vascular tissues [47]. In the present study, considering whole arterial wall, hemodynamic forces did not significantly affect xanthine oxidase activity. This may explain xanthine oxidase as a weak inducer of ROS in arterial wall.

Table 1: Biochemical analysis of various enzymes from rabbit thoracic aorta under hemodynamic stress conditions.

\begin{tabular}{|c|c|c|c|c|c|}
\hline $\begin{array}{l}\text { Hemodynamic } \\
\text { Conditions } \\
\text { Enzymatic analysis } \\
\nabla\end{array}$ & $\begin{array}{l}\text { Normal/ } \\
\text { Control } \\
\text { Aorta }\end{array}$ & $\begin{array}{l}\text { Under } \\
\text { laminar } \\
\text { shear stress } \\
\text { at } \\
70 \mathrm{~cm} \text { water }\end{array}$ & $\begin{array}{l}\text { Under } \\
\text { laminar } \\
\text { shear stress } \\
\text { at } \\
150 \text { water }\end{array}$ & $\begin{array}{l}\text { Under } \\
\text { pulsatile } \\
\text { shear stress } \\
\text { at } 70 \mathrm{~cm} \\
\text { water }\end{array}$ & $\begin{array}{l}\text { Under } \\
\text { pulsatile } \\
\text { shear stress } \\
\text { at } 150 \mathrm{~cm} \\
\text { water }\end{array}$ \\
\hline $\begin{array}{l}\text { 1. } \begin{array}{l}\text { Superoxide } \\
\text { dismutase } \\
\text { (SOD) }\end{array} \\
\text { 2. Catalase (CAT) } \\
\text { 3. Glutathione } \\
\text { Peroxidase } \\
\text { (GPx) } \\
\text { 4. Glutathione } \\
\text { reductase (GR) } \\
\text { 5. Glucose-6- } \\
\text { phosphate } \\
\text { dehydrogenase } \\
\text { (G6PD) }\end{array}$ & $\begin{array}{l}24 \pm 2.0 \\
5.9 \pm 0.11 \\
8.5 \pm 0.76 \\
2.9 \pm 0.27 \\
7.1 \pm 0.1 \\
100 \pm 8.1\end{array}$ & $\begin{array}{l}160 \pm 6.4^{* *} \\
29 \pm 1.5^{*} \\
8.8 \pm 0.85^{* *} \\
5.4 \pm 0.40^{* *} \\
0.8 \pm 0.07^{* *} \\
6.5 \pm 0.86^{*} \\
87 \pm 9.8\end{array}$ & $\begin{array}{l}170 \pm 6.4^{* *} \\
17 \pm 0.6^{* *} \\
7.8 \pm 0.59^{*} \\
4.6 \pm 0.76^{*} \\
1.9 \pm 0.056^{*} \\
11.0 \pm 1.1^{* *} \\
92 \pm 8.2\end{array}$ & $\begin{array}{l}86 \pm 6.8 * * * \\
9.5 \pm 0.6 * *\end{array}$ & $\begin{array}{l}59 \pm 5.7 * \\
6.0 \pm 0.8 \\
4.1 \pm 0.41^{*} \\
12 \pm 1.7^{* *} \\
4.7 \pm 0.22^{*} \\
13 \pm 1.0 * * \\
110 \pm 11.0\end{array}$ \\
\hline
\end{tabular}

Experimental protocol: All the estimations were made spectrophotometrically, using homogenate and post mitochondrial supernatant (PMS) of the tissue. [Xanthine oxidase ( $\mu \mathrm{g} / \mathrm{g}$ tissue), Catalase ( $\mathrm{nmol}$ of $\mathrm{H}_{2} \mathrm{O}_{2}$ consumed $/ \mathrm{min} / \mathrm{mg}$ protein), Glutathione peroxidase (nmole of NADPH oxidized/ $\mathrm{min} / \mathrm{mg}$ protein), Glutathione reductase (nmole of NADPH oxidized/ $\mathrm{min} / \mathrm{mg}$ protein), G6PD (nmole of NADP reduced/ min/ mg protein), SOD 
(units $/ \mathrm{ml}$ ), GST (nmole CDNB conjugate formed/ $\mathrm{min} / \mathrm{mg}$ protein). Statistics: Mean \pm SE, at significance level of $\mathrm{P}<0.05^{*}, \mathrm{P}<0.01 * *$ and $\left.\mathrm{P}<0.001 * * *\right]$.

Table 2: Biochemical analysis of oxidative stress markers from rabbit thoracic aorta under hemodynamic stress conditions

\begin{tabular}{|l|l|l|l|l|l|}
\hline $\begin{array}{l}\text { Hemodynamic } \\
\text { Conditions }\end{array}$ & $\begin{array}{l}\text { Normal/ } \\
\text { Control } \\
\text { Aorta }\end{array}$ & $\begin{array}{l}\text { Under } \\
\text { laminar shear } \\
\text { stress at 70 cm } \\
\text { water }\end{array}$ & $\begin{array}{l}\text { Under } \\
\text { laminar shear } \\
\text { stress at } 150 \\
\text { water } \\
\text { analysis } \boldsymbol{V}\end{array}$ & $\begin{array}{l}\text { Under } \\
\text { pulsatile } \\
\text { shear stress } \\
\text { at } 70 \mathbf{c m} \\
\text { water }\end{array}$ & $\begin{array}{l}\text { Under } \\
\text { pulsatile } \\
\text { shear tress } \\
\text { at } 150 \mathbf{c m} \\
\text { water }\end{array}$ \\
\hline $\begin{array}{l}1 . \text { Reduced } \\
\text { glutathione } \\
\text { (GSH) }\end{array}$ & $4.9 \pm 0.23$ & $6.1 \pm 0.31^{*}$ & $6.5 \pm 0.34^{*}$ & $3.3 \pm 0.21^{*}$ & $3.7 \pm 0.14^{*}$ \\
\hline $\begin{array}{l}\text { 2. Lipid } \\
\text { Peroxidation } \\
\text { (LPO) }\end{array}$ & $39 \pm 3.0$ & $45 \pm 4.5$ & $60 \pm 10.0^{*}$ & $40 \pm 2.0$ & $67 \pm 7.9 *$ \\
\hline
\end{tabular}

Experimental protocol: All the estimations were made spectrophotometrically, using homogenate and post mitochondrial supernatant (PMS) of the tissue. GSH (nmole of GSH/gm tissue), LPO: TBARS (nmol/mg Protein), [Statistics: Mean $\pm \mathrm{SE}$, at significance level of $\mathrm{P}<0.05^{*}$ ].

Table 3: Biochemical analysis of antioxidant markers showing \% increase $(\uparrow)$ or decrease $(\downarrow)$ vs. control, under hemodynamic stress conditions

\begin{tabular}{|c|c|c|c|c|}
\hline $\begin{array}{l}\text { Hemodynamic } \\
\text { Conditions } \\
\text { Enzymatic } \\
\text { analysis } \\
\nabla\end{array}$ & $\begin{array}{l}\text { Under } \\
\text { laminar } \\
\text { shear } \\
\text { stress at } \\
70 \mathrm{~cm} \\
\text { water }\end{array}$ & $\begin{array}{l}\text { Under } \\
\text { laminar } \\
\text { shear } \\
\text { stress at } \\
150 \mathrm{~cm} \\
\text { water }\end{array}$ & $\begin{array}{l}\text { Under } \\
\text { pulsatile } \\
\text { shear } \\
\text { stress at } \\
70 \mathrm{~cm} \\
\text { water }\end{array}$ & $\begin{array}{l}\text { Under } \\
\text { laminar } \\
\text { shear stress } \\
\text { at } 150 \mathrm{~cm} \\
\text { water }\end{array}$ \\
\hline 1. SOD & $19 \% \uparrow$ & $24 \% \uparrow$ & $34 \% \downarrow$ & $46 \%$ \\
\hline 2. Catalase & $17 \% \uparrow$ & $29 \% \downarrow$ & $60 \% \downarrow$ & $75 \% \downarrow$ \\
\hline 3. $\mathrm{GPx}$ & $33 \% \uparrow$ & $24 \% \uparrow$ & $63 \% \downarrow$ & $30 \% \downarrow$ \\
\hline
\end{tabular}

It is interesting to note that pulsatile shear stress downregulates the basal antioxidant defense in blood vessels in hypertensive state $(150 \mathrm{~cm}$ water), whereas laminar shear stress may play a protective role in vasculature. These results are in agreement with earlier studies [17, 48, 49], which have reported an atheroprotective role of laminar shear stress. We speculate that differences in arterial wall redox state, coordinated by different regimens of hemodynamic stresses, may contribute to the focal nature of atherosclerosis.

Table 4: Biochemical analysis of oxidative stress markers showing \% increase $(\uparrow)$ or decrease $(\downarrow)$ vs. control, under hemodynamic stress conditions

\begin{tabular}{|c|c|c|c|c|}
\hline $\begin{array}{l}\text { Hemodynamic } \\
\text { Conditions } \\
\text { Enzymatic } \\
\text { analysis } \\
\nabla\end{array}$ & $\begin{array}{l}\text { Under } \\
\text { laminar } \\
\text { shear } \\
\text { stress at } \\
70 \mathrm{~cm} \\
\text { water }\end{array}$ & $\begin{array}{l}\text { Under } \\
\text { laminar } \\
\text { shear } \\
\text { stress at } \\
150 \mathrm{~cm} \\
\text { water }\end{array}$ & $\begin{array}{l}\text { Under } \\
\text { pulsatile } \\
\text { shear } \\
\text { stress at } \\
70 \mathrm{~cm} \\
\text { water }\end{array}$ & $\begin{array}{l}\text { Under } \\
\text { laminar } \\
\text { shear stress } \\
\text { at } 150 \mathrm{~cm} \\
\text { water }\end{array}$ \\
\hline 1. GSH & $20 \% \uparrow$ & $25 \% \uparrow$ & $33 \% \downarrow$ & $24 \% \downarrow$ \\
\hline 2. LPO & $13 \% \uparrow$ & $35 \% \uparrow$ & $2.5 \% \uparrow$ & $48 \% \uparrow$ \\
\hline
\end{tabular}

Present study demonstrated that pathophysiologically relevant levels of cyclic/pulsatile flow and pressure promote ROS formation and GSH depletion in rabbit thoracic aorta, which, in turn, induce G6PDH expression and increase G6PDH activity. We further 
observed that hydrostatic pressure does not have a uniform influence on arterial wall redox state. In conclusion, results suggest that pulsatile flow induces a general increase in the oxidative state of vascular endothelial and smooth muscle cells, which is mediated by downregulation of the production of vascular superoxide dismutase with a consequent increase in superoxide anion production. Taken together with the results (unpublished data), regarding regulation of $\mathrm{NO}$ production by different hemodynamic environments, it is speculated that in case of laminar flow regimen, the balance between NO and superoxide anion productions is well preserved, whereas under pulsatile flow, it is in favor of superoxide anion. Thus, the flow induced oxidative stress and pressure response seems to be associated with vascular wall dysfunction as it is evident by altered reactivity of antioxidants and increased levels of aortic prooxidants under pulsatile shear stress. It can be speculated that endothelial or vascular oxidative damage may arise not only when free radical production is excessive but also at normal physiological state, if not regulated by well-organized and accessible defense mechanisms.

In conclusion, these findings have implications for the use of anti-oxidative therapy in hypertension. Present study has also reviewed evidences that lead to postulate that hypertension predisposes to and accelerates atherosclerosis, at least in part, because of synergy between elevated blood pressure and other atherogenic stimuli to induce oxidative stress on the arterial wall [50]. We therefore hypothesized that, in both normotensive and hypertensive situations, steady laminar shear stress may induce compensatory antioxidant defense mechanisms by increasing the production of SOD. In the present study, similar increases in catalase activity with laminar shear stress were also observed in vessels exposed to hemodynamic forces.

\section{Acknowledgments}

HSY Acknowledges Council of Scientific and Industrial Research (CSIR), New Delhi and Hamdard University, Delhi for providing financial assistance and necessary infrastructure for the study, respectively.

\section{References}

1. Malek, A. M., Alper, S. L., and Izumo, S. Hemodynamic shear stress and ts role in atherosclerosis. J. Am. Med. Assoc. 1999, 282, 2035-2042.

2. Griendling, K. K., and FitzGerald, G. A. Oxidative stress and cardiovascular injury. II. Animal and human studies. Circulation, 2003, 108, 2034-2040.

3. Griendling, K. K., and FitzGerald, G. A. Oxidative stress and cardiovascular injury. I. Basic mechanisms and in vivo monitoring of ROS. Circulation, 2003, 108, 1912-1916.

4. Bagi, Z., Z. Ungvari, A. Koller, Xanthine Oxidase-Derived Reactive Oxygen Species Convert Flow-Induced Arteriolar Dilation to Constriction in Hyperhomocysteinemia. Arterioscl. Thromb. Vasc. Biol. 2002;22:2833.

5. Silacci, P., A. Desgeorges, L. Mazzolai, C. Chambaz, D. Hayoz, Flow Pulsatility Is a Critical Determinant of Oxidative Stress in Endothelial Cells. Hypertension. 2001; 38:162-1169.

6. Takeshita, S., N. Inoue, T. Ueyama, S. Kawashima, M. Yokoyama, Shear stress enhances glutathione peroxidase expression in endothelial cells. Biochem. Biophys. Res. Commun. 2000;273:66-71.

7. Buga, G.M., M.E. Gold, J.M. Fukuto, L.J. Ignarro, Shear stress induced release of nitric oxide from endothelial cells grown on beads. Hypertension. 1991;17:187-193.

8. Franke, R., M. Gräfe, H. Schnittler, D Seiffge, C. Mittermayer, Induction of human vascular endothelial stress fibers by fluid shear stress. Nature. 1984;307:648-649

9. Halliwell, B., Free radicals, reactive oxygen species and human disease: a critical evaluation with special reference to atherosclerosis. Br. J. Exp. Pathol. 1989;70:737-757.

10. Rubanyi, G.M., P.M. Vanhoutte, Oxygenderived free radicals, endothelium and 
responsiveness of vascular smooth muscle. Am. J. physiol. 1986;250:H815-H8212.

11. Stralin, P., K. Karlsson, B.O. Johansson, S.L. Marklund, The Interstitium of the Human Arterial Wall Contains Very Large Amounts of Extracellular Superoxide Dismutase. rosis, Thrombosis, and Vascular Biology. 1995; 15:2032-2036.

12. Howard, A.B., R.W. Alexander, R.M. Nerem, K.K. Griendling, W.R. Taylor, Cyclic strain induces an oxidative stress in endothelial cells. Am. J. Physiol. 1997;272:C421-C427.

13. Hsieh, H.J., C.C. Cheng, S.T. Wu, J.J. Chiu, B.S. Wung, D.L. Wang, Increase of reactive oxygen species (ROS) in endothelial cells by shear flow and involvement of ROS in shearinduced c-fos expression. J. Cell. Physiol. 1998;175:156-62.

14. Kuo, L., W.M. Chilian, M.J. Davis, Interaction of pressure and flow induced responses in porcine coronary resistance vessels. Am. J. Physiol. 1985;261:H1706H1715.

15. Inoue N. Vascular C-reactive protein in the pathogenesis of coronary artery disease: role of vascular inflammation and oxidative stress. Cardiovasc Hematol Disord Drug Targets. 2006 Dec;6(4):227-31.

16. Gosgnach, W., D. Messika-Zeitun, W Gonzales, M. Philippe, J.B. Michel, Shear stress induces iNOS expression in cultured smooth muscle cells: role of oxidative stress. Am. J. Physiol. 2000;279:C1880-C1888.

17. Radomski, M.W., E. Salas, Nitric oxidebiological mediator, modulator and factor of injury: its role in the pathogenesis of atherosclerosis. Atherosclerosis. 1995;118:6980.

18. Cuccurullo, F, Porreca E, Lapenna D, Pennelli A, Savini F, Mezzetti A, Marzio L, Ricci G, Del Boccio G. Aortic glutathione-related antioxidant defences in rabbits subjected to suprarenal aortic coarctation hypertension. J. Mol. Cell. Cardiol. 1991; 23:727-34.

19. Wolin, M.S., Interactions of Oxidants With Vascular Signaling Systems. Arteriosclerosis, Thrombosis, and Vascular Biology. 2000;20:1430-1439.
20. Davidson, C.A., P.M Kaminski, M.S. Wolin, Nitric oxide elicits prolonged relaxation of bovine pulmonary arteries via endogenous peroxynitrite generation. Am. J. Physiol. 1997;273:L437-L444.

21. Mohazzab, H., P.M. Kaminski, M.S. Wolin, NADH oxidoreductase is a major source of superoxide anion in bovine coronary artery endothelium. Am. J. Physiol. 1994; 266:H2568-H2572.

22. A.L. Baldwin, L.M. Wilson, B.R. Simon. Effect of pressure on aortic hydraulic conductance. Arterioscl. Thromb. 1992;12:163-171.

23. H.R. Brunner. Spontaneous diameter oscillations of the radial artery in humans. Am. J. Physiol. 1993;264:H2080-H2084.

24. Stirpe F and Della Corte E. The regulation of rat liver xanthine oxidase. Involvement of thiol groups in the conversion of enzyme activity from dehydrogenase (Type D) into oxidase (Type O) and purification of the enzyme. Biochem. J. 1969;126:739-745.

25. Bernheim F, Bernheim M.L., Wilbur K.M. The reaction between thiobarbituric acid and the oxidation products of certain lipides. J Biol Chem. 1948 May;174(1):257-64.

26. Jollow, D.J., J.R. Mitchell, M. Zampaglione, J.R. Gillete, Bromobenzene induced liver necrosis: Protective role of glutathione and evidence for 3,4-bromobenzene as the hepatotoxic intermediate. Pharmacol. 1974;11:151-169.

27. Ali, S., G. Diwakar, S Pawa, Paraquat induces different pulmonary biochemical responses in Wistar rats and Swiss mice. Chem. Biol. Interactions. 2000;125:79-91.

28. Marklund, S., G. Marklund, Involvement of the superoxide anion radical in the autoxidation of pyrogallol and a convenient assay for superoxide dismutase. Eur J. biochem. 1974;47:469-474.

29. Carlberg, I., B. Mannervik, Purification and characterization of the flavoenzyme glutathione reductase from rat liver. J. Biol. Chem. 250 (1975) 5475-5480.

30. Mohandas, J., J.J. Marshall, G.G. Duggin, J.S. Horvath, D. Tiller, Differential distribution of glutathione related enzymes in rabbit kidney: 
possible implications in analgesic neuropathy. Cancer Res. 1984;44:5086-91.

31. Claiborne, A., Catalase activity. In CRC, Handbook of Methods for Oxygen Radical Research (ed. RA Greenwald) CRC Press, Boca Raton, FL, 1985; p283-284.

32. Habig, W.H., M.J. Pabst, W.B. Jakoby, Glutathione-S-transferase. The first enzymatic step in mercapturic acid formation. J. Biol. Chem. 1974;249:7130-7139.

33. Zaheer, N., K.K. Tiwari, P.S. Krishnan, Exposure and solubilization of hepatic mitochondrial shunt dehydrogenases. Arch. Biochem. Biophys. 1965;109:646-648.

34. Lowry, O.H., A.L. Rosenbrough, A.L. Farr, R.L. Randall, Protein measurement with Folin phenol reagent. J. Biol. Chem. 1951;193:265275.

35. Wilson, E., Q. Mai, K. Sidhir, R.H. Weiss, H.E. Ives, Mechanical strain induces growth of vascular smooth muscle cells via autocrine action of PDGF. J Cell. Biol. 1993;123:741747.

36. Hishikawa, K., T.F. Lüscher, Pulsatile stretch stimulates superoxide production in human aortic endothelial Cells. Circulation. 1997;96:3610-3616.

37. Winterbourn, C.C., A. Stern, Human red cells scavenge extracellular hydrogen peroxide and inhibit formation of hypochlorous acid and hydroxyl radical. J Clin Invest. 1987;80:14861491.

38. De Keulenaer, G.W., D.C. Chappell, N. Ishizaka, R.M. Nerem, R.W. Alexander, K.K. Griendling, Oscillatory and steady laminar shear stress differentially affect human endothelial redox state: role of a superoxideproducing NADH oxidase. Circ. Res. 1998; 82:1094-1101.

39. Pandolfi, P., F. Sonati, R. Rivi, P. Mason, F. Grosveld, J. Luzzatto, Targeted disruption of the housekeeping gene encoding glucose 6phosphate dehydrogenase (G6PD): G6PD is dispensable for pentose synthesis but essential for defense against oxidative stress. EMBO. J. 1995; 14:5209-5215.

40. Will, Y., Current Protocols in Toxicology. New York: Wiley, 1999.
41. Thubrikar, M.J., F. Robicsek, PressureInduced Arterial Wall Stress and Atherosclerosis. Ann. Thorac. Surg. 1995; 59:1594-1603.

42. Jane, A.L., J. Loscalzo, Cyclic strain modulates resistance to oxidant stress by increasing G6PDH expression in smooth muscle cells. Am. J. Physiol. 2000; 279:H2477-H2485.

43. Halliwell, B., J.M. Gutteridge, Protection against oxidants in biological systems: the superoxide theory of oxygen toxicity. In: Free Radicals in Biology and Medicine (2nd ed.), Clarendon Press, Oxford, UK. 1989; p87-187.

44. Ohara, Y., T.E. Peterson, D.G. Harrison, Hypercholesterolemia increases endothelial superoxide anion production. J. Clin. Invest. 1993; 91:2546-2551.

45. Patrick, J.P., I. Yashushi, K. Tornheim, An NADPH oxidase superoxide generating system in the rabbit aorta. Am. J. physio. 1995; 268:H2274-H2280.

46. Griendling, K.K., C.A. Minieri, D. Ollerenshaw, R.W. Alexander, Angiotensin II stimulates NADH and NADPH oxidase activity in cultured vascular smooth muscle cells. Circ. Res. 1994; 74:1141-1148.

47. Terada LS, Rubinstein JD, Lesnefsky EJ, Horwitz LD, Leff JA, Repine JE. Existence and participation of xanthine oxidase in reperfusion injury of ischemic rabbit myocardium. Am J Physiol. 1991 Mar;260(3 Pt 2):H805-10.

48. Topper, J.N., M.A. Gimbrone, Jr., Blood flow and vascular gene expression: fluid shear stress as a modulator of endothelial phenotype. Mol. Med. Today. 1999;5:40-46.

49. Topper, J.N., J. Cai, D. Falb, M.A. Gimbrone, Jr., Identification of vascular endothelial genes differentially responsive to fluid mechanical stimuli: cyclooxygenase-2, manganese superoxide dismutase, and endothelial cell nitric oxide synthase are selecively upregulated by steady laminar shear stress. Proc Natl. Acad. Sci. USA. 1996; 93:10417-10422.

50. Hamet, P., D. deBlois, T. V. Dam, L. Richard, E. Teiger, B. S. Tea, S. N. Orlov, J. Tremblay, Apoptosis and vascular wall remodeling in 
hypertension. Can. J. Physiol. Pharmacol. 1996;74:850-861.

51. McCord, J.M., I. Fridovich, Superoxide dismutase: An enzyme function for erythrocuprein (hemocuprein). J. Biol. Chem. 1969;244:6049-6055. 